\title{
高精度非球面ミラーの加工技術
}

\author{
佐野泰久, 三村秀和, 山村和也, 山内和人, 森勇藏 \\ 大阪大学大学院 工学研究科 (广565-0871 大阪府吹田市山田丘2-1)

\section{Ultraprecision Machining Method for Ultraprecise Aspherical Mirror} \\ Yasuhisa SANO, Hidekazu MIMURA, Kazuya YAMAMURA, \\ Kazuto YAMAUCHI, and Yuzo MORI \\ Graduate School of Engineering, Osaka University, 2-1 Yamadaoka, Suita, Osaka 565-0871
}

(Received October 3, 2006)

\begin{abstract}
An ultraprecise aspherical mirror, which is difficult to fabricate by conventional mechanical machining, is required for optics, particularly in the field of coherent hard X-rays or extreme-ultraviolet lithography. In this review, we introduce new fabrication methods of elastic emission machining (EEM) and plasma chemical vaporization machining (PCVM). They are noncontact machining methods using chemical reactions and enable ultraprecise numerically controlled figuring by dwell time control. We also introduce ultraprecise aspheric ellipsoid mirrors for focusing hard X-rays fabricated using PCVM and EEM with a new figure testing method, were found to achieve nearly diffraction-limited focusing performance.
\end{abstract}

Key Words: Ultraprecision machining, Hard X-rays, Focusing mirror, EEM, Plasma CVM

\section{1.はじめに}

近年，紫外から硬X線の広波長領域において高輝度かつ 優れたコヒーレンシーをもつ光源が, SPring-8に代表され る第3世代のシンクロトロン放射光施設によって実現され ている。このような放射光は, 基礎学問領域において幅 広く利用されているが, 中でもX線顕微鏡への応用は, 細 胞や蛋白質の非破壊分析が可能なため, 医学, 生命科学 といった学問領域から注目されている.X線顕微鏡には高 輝度かつ極微小径のX線ビームが求められており, そのた め極めて高精度な光学素子の開発が盛んに行われてい る $^{1,2)}$. 一方, 早期実用化が望まれている極端紫外線りソ グラフィーシステムにおいても, 形状誤差および表面粗 さがあらゆる空間波長において $1 \mathrm{~nm}$ 以下という極めて精度 の高い反射鏡が要求されている.

一般に平面や球面に比べ非球面を高精度に仕上げるこ とは困難であり, 様々な加工技術が開発されている. 従 来の機械研磨を応用したCCP (Computer Controlled Polishing)は，ワーク上における小径ピッチポリッシャの 滞在時間をコンピュータ制御して修正加工を行う方法3-9) で, 概ね $0.1 \sim 10 \mathrm{~mm}^{3} / \mathrm{h}$ の体積加工速度で, $50 \mathrm{~nm}$ peak-tovalley (p-v) 程度の形状精度が実現可能である. IBF (Ion Beam Figuring)は，イオンスパッタリングを応用したもの で，ワーク各場所におけるイオンビーム照射量をコン ピュータ制御することで任意の形状加工を行う方法であ
る ${ }^{9-13)}$. 加工速度は $0.05 \sim 2 \mathrm{~mm}^{3} / \mathrm{h}$ 程度とCCPに劣るが, 形 状精度はCCPよりも優れており，1 nm p-vに迫る例も報告 されている9). その他, 磁性流体研磨 (Magnetorheological Finishing; MRF) ${ }^{14-16)}$ や, PACE (Plasma Assisted Chemical Etching) ${ }^{17,18)}$, PJCE (Plasma Jet Chemical Etching) ${ }^{19)}$ 等, $\mathrm{CCP}$ 程度の形状精度を有しつつ, 高能率な方法が提案され ている。

我々のグループでは, 原子オーダで平滑な表面を形成 可能なEEM (Elastic Emission Machining) ${ }^{20-23)}$ や, 高能率に ナノメートルオーダの形状加工が可能なプラズマCVM (Chemical Vaporization Machining) ${ }^{26-32)}$ といった独自の加工 法を開発してきた。本稿では, EEMおよびプラズマCVM の概要について紹介するとともに, これらの加工法を用 いて製作した硬X線集光用非球面ミラーについて解説す る.

\section{EEMおよびプラズマCVMによる超精密加エ}

\subsection{EEM}

EEMは, 微粒子表面と被加工物表面間の化学反応を利 用した超精密加工法である. Fig. 1に加工原理を示す。微 粒子は超純水の流れによって被加工物表面に供給され, 被加工物表面近傍に形成されたせん断流によって, 被加 工物表面を転がり, やがて流れに乗って被加工物表面か ら離脱する。微粒子が被加工物表面に接触した際, 両者 


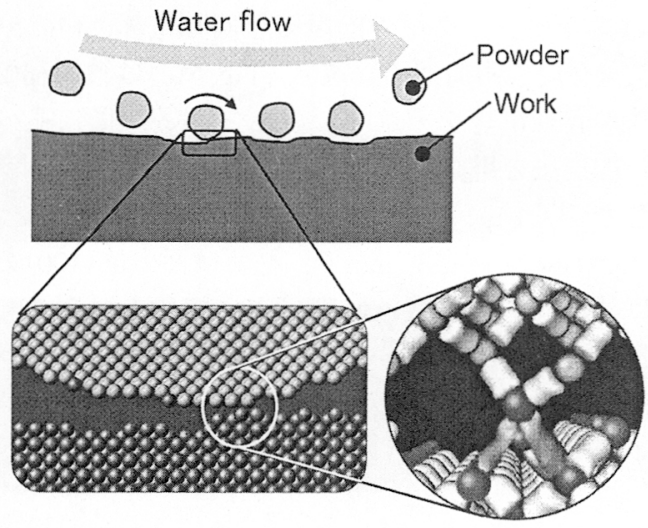

Fig. 1 Schematic of machining mechanism of EEM.

の組み合わせ次第で微粒子表面原子と被加工物表面原子 の間に化学結合が生じる。たとえばシリコンを加工する 場合は微粒子 $\left(\mathrm{SiO}_{2}, \mathrm{ZrO}_{2}\right.$ 等 $)$ 表面の酸素原子が被加工物表 面のシリコン原子と結合する。被加工物表面原子と微粒 子表面原子との間の結合力が，被加工物表面原子と被加 工物第二層原子との間の結合力よりも大きい場合，被加 工物表面原子は微粒子の運動に伴って被加工物表面から 離脱し，加工が進行する。通常，EEMでは微粒子と超純 水を混合した加工液を作製し，加工液を被加工物表面に 供給することによって加工を行う。加工液の供給方法に は, 被加工物と回転球間に生じる弾性流体潤滑流れを利 用する方法と，加圧した加工液をノズルから被加工物に 向けて噴出する方法が用いられている。EEMの特徴の一 つは, 通常の研磨とは異なり化学反応に基づく加工であ るという点である。量子力学の第一原理に基づく分子動

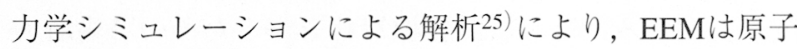
単位の加工であることが確認されている。 また，シリコ ンウエハを試料として, 加工面の表面準位密度を測定し た結果, EEM加工面の表面準位密度は通常の研磨面に比 ベて1/20以下であり，ケミカルエッチング面と同程度しか 存在しないことが分かっている24).これは, EEM加工面 には殆ど欠陥が存在していないことを示している，EEM のもう一つの特徽として，原子レベルの平滑面が自動的 に形成される点が挙げられる。先に述べたとおり，EEM では微粒子表面原子に結合した被加工物表面原子が化学 反応に基づき除去されるため，微粒子の接しない部分は 除去されない.すなわちEEMは，化学反応に基づいた加 工でありながら，被加工物表面上の凹部は除去されず凸 部のみが優先的に除去されていく特性を有している23).

Fig. 2はEEMを用いて加工したSi (001) 基板の表面を走査卜 ンネル顕微鏡 (Scanning Tunneling Microscope; STM)を用 いて観察した結果である22). $20 \mathrm{~nm}$ 四方を観察したもので あるが，個々の原子が完全に解像できていることが分か る。一般にSTMによって観察されているSi $(001)$ 表面は, 超高真空中での高温アニールにより再構成された表面が ほとんどであり，このように超精密加工表面を直接観察 したものは他に類を見ない.またFig. 3 は100 nm四方を観 察した結果を原子層毎に分けて解析した例であるが，Fig. 3(b)の層を基準として, 一層手前の層 (Fig. 3(c)) と一層奥

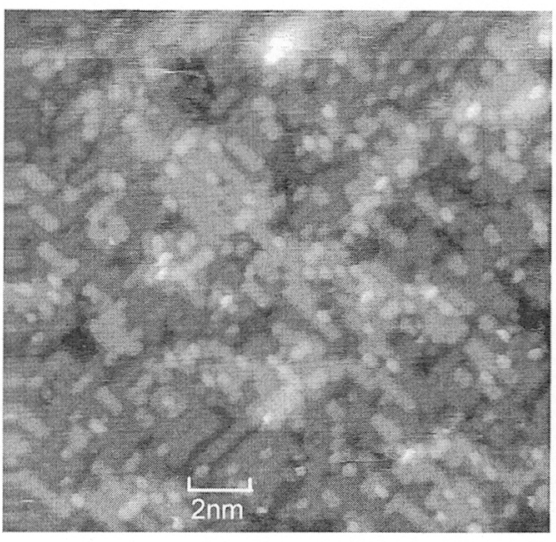

Fig. 2 Scanning tunneling microscopy image $(20 \mathrm{~nm} \times 20$ $\mathrm{nm})$ of $\mathrm{Si}(001)$ surface after EEM process.

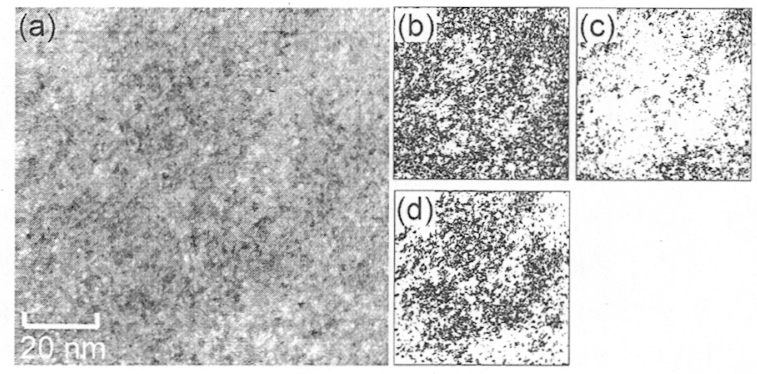

Fig. 3 (a) Scanning tunneling microscopy image (100 nm $\times 100 \mathrm{~nm}$ ) of $\mathrm{Si}(001)$ surface after EEM process. (b) Spatial distribution of most frequent atomic layer, (c) that of layer above (b), and (d) that of layer below (b).

の層 (Fig. 3(d))の合計3層に, 全体の95\%以上の原子が属 していることが分かり，極めて平坦な表面であることが 分かった。

\section{2 プラズマCVM}

EEMは前述の通り原子単位の加工法であり原子オーダ で平滑な面を作製できるが，加工速度が非常に小さいた め最終仕上げ加工に適した方法である。このためEEMに 先行して加工面に欠陥をもたらさず比較的短時間でナ， メートルオーダの精度を有する高能率な加工法を用いる 必要がある。著者らはそのような加工法としてプラズマ CVMを開発した26,30).プラズマCVMは, 大気圧プラズマ 中で生成された高密度の中性ラジカルと被加工物表面原 子との化学反応を用いた高能率超精密加工法である. Fig. 4に加工原理を示す．フッ素や塩素等を含むハロゲン化合 物ガスとヘリウムやアルゴン等の不活性ガスの混合ガス を反応ガスとして加工装置内に充填し, 被加工物と電極 間に高周波電界を印加することでプラズマを発生させ る。プラズマ中では八ロゲン化合物ガスから極めて活性 なハロゲン中性ラジカルが生成され, 被加工物表面原子 はこれらの中性ラジカルと化学結合することで揮発性物 質となって表面から離脱し，加工が進行する。このよう に加工原理そのものは, 半導体製造プロセス等で用いら れる低圧のプラズマエッチングと同様であるが, 反応ガ 


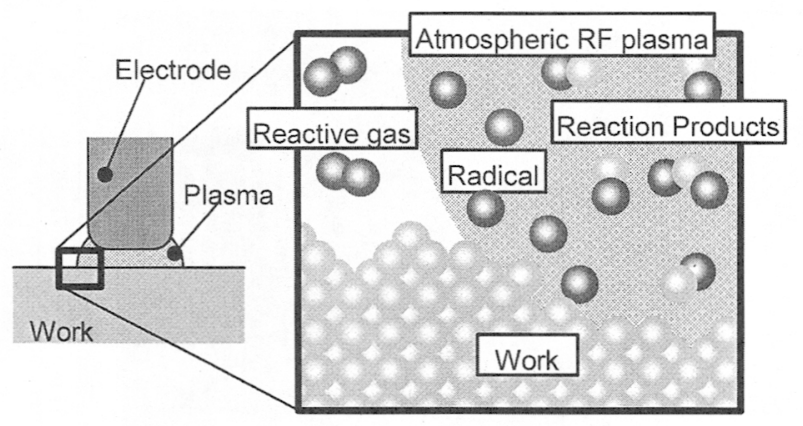

Fig. 4 Schematic of machining mechanism of PCVM.

ス圧力が大気圧であることから, 次のような3つの特徴を 有する。まず，ガス密度が大きいためプラズマ中で生成 される中性ラジカル密度が大きく, 研削や研磨といった 機械加工に匹敵する加工速度で無歪加工が可能であるこ と, そして, 反応ガスの平均自由行程が小さいためプラ ズマは被加工物と電極の間の電界強度の大きい領域のみ に局所的に発生させることが可能であり，機械加工に匹 敵する高い空間分解能を得ることができること, さら に, 同じく平均自由行程が小さいため, プラズマ中の平 均イオンエネルギーが小さく, 被加工物表面に対するイ オン損傷が極めて小さいこと, である.プラズマCVMで は, 加工用電極の形状により, 様々な応用が検討されて いる. Fig. 5(a)のワイヤー電極は比較的薄い基板の切断や 薄膜のパターニング27)等に適しており, Fig. 5(b)のパイプ 電極は加工能率よりも空間分解能が要求される際に用い られている28,29). これらの電極は構造が簡便で良好な空間 分解能が得られる反面, 電極の耐熱性の問題から投入で きる電力の上限が小さく, 加工能率が要求される場合に は適さない. Figs. 5 (c)，（d），（e）に示す電極は回転電極 と呼ばれている。大気圧雲囲気下において電極を回転さ せることで電極表面近傍には粘性によるガスの流れが生 じ, 加工部への反応がスの供給と加工部からの反応生成 物の排出を高能率に実現できると共に，ガスの流れによ る冷却効果から大電力の投入が可能になる. そのため, 回転電極を用いることで高能率な加工が実現できる。Fig. (a)

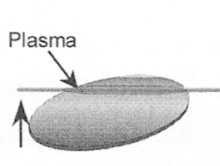

(d)

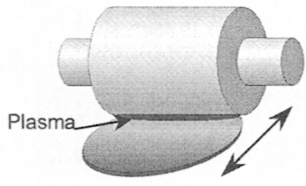

(b)

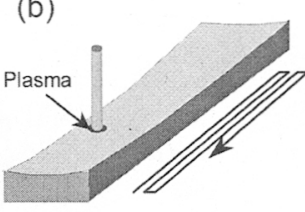

(e)

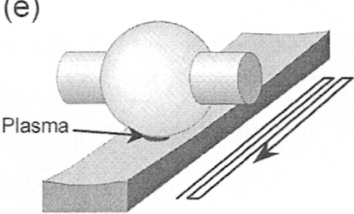

(c)

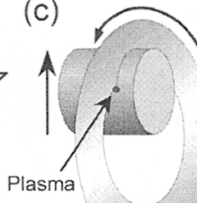

Fig. 5 Electrode types for PCVM. (a) wire type for cutting and patterning, (b) pipe type for fine figuring, (c) inner-blade type for slicing, (d) cylindrical type for polishing, and (e) sphere type for numerically controlled figuring. 5(c) はスライシング用の内周刃型回転電極, Fig. 5 (d) は ポリシング用の円筒型回転電極, Fig. 5 (e) は数值制御加工 用の球型回転電極をそれぞれ表している。後に述べる数 值制御加工法を用いてプラズマCVMにより平面ミラーを 加工した例をFig. 6に示す。ミラーの大きさは長さ400 $\mathrm{mm}$, 幅 $50 \mathrm{~mm}$, 厚さ30 mmで, 材質は面方位 $(100)$ のシリ コン単結晶である。機械研磨によって仕上げられた前加 工面の平面度は $158 \mathrm{~nm}$ p-vであったが, 数值制御プラズマ

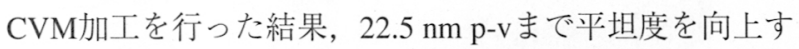
ることができている。

\section{3 数值制御加工法}

EEM，プラズマCVMは共に工具に相当する加工液供給 用ノズルゃプラズマ発生用電極とワークが接触しない加 工法であるため, 数值制御加工は微粒子供給時間もしく はプラズマ照射時間，すなわちワーク表面上における反 応種の滞在時間制御によって行う。工具とワークが接触 する研削や研磨といった加工法においては, それらの相 対位置関係あるいは接触圧力等が加工にとって重要なパ ラメータとなるため, 加工中に生ずる僅かな振動や熱変 形が直接加工精度に対して悪影響を及ぼす。これに対 し, EEMやプラズマCVMにおいては, 通常, 工具とワー クの間に数百 $\mu \mathrm{m}$ から $1 \mathrm{~mm}$ 程度の間隙を設けているため, 多少の振動や熱変形は加工精度に殆ど影響を与えない. また, 両者とも加工原理は化学反応であり加工面に加工 歪層が形成されないことから, 加工に伴う残留応力は発 生せず，加工後にワークが反ったり，経時変化によって ワーク形状が変化したりすることも無い. Fig. 7に具体的 な数值制御加工手順を示す。まず, 前加工面形状を高精 度に計測する。そして，目標形状を得るための各場所の 加工量を算出し, 予め取得済みのワークテーブル静止状 態での単位加工痕形状でデコンボリューションをとるこ とで, 各場所の滞在時間分布を算出する。 その後, 微粒 子を供給またはプラズマを発生させた状態で，滞在時間 の逆数に相当する送り速度分布でワークテーブルを走査 して加工を行う。加工後は再度ワーク形状を計測し, 加 工と計測を繰り返すことで, 要求精度に到達する.

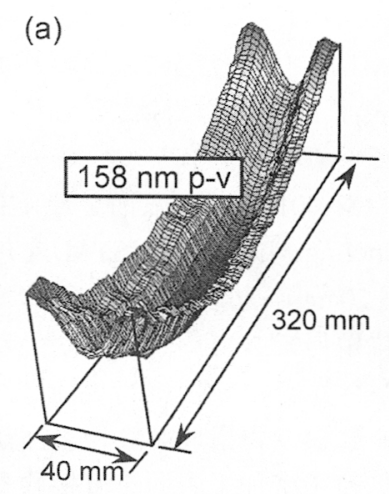

(b)

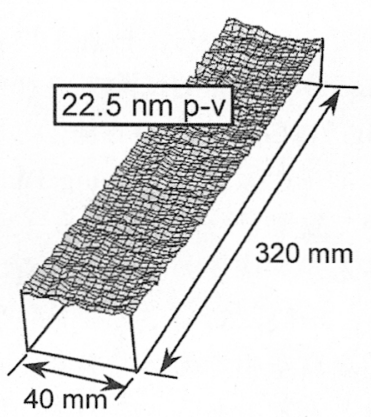

Fig. 6 X-ray flat mirror fabricated by numerically controlled PCVM. (a) Premachined surface profile and (b) figured surface by PCVM. 


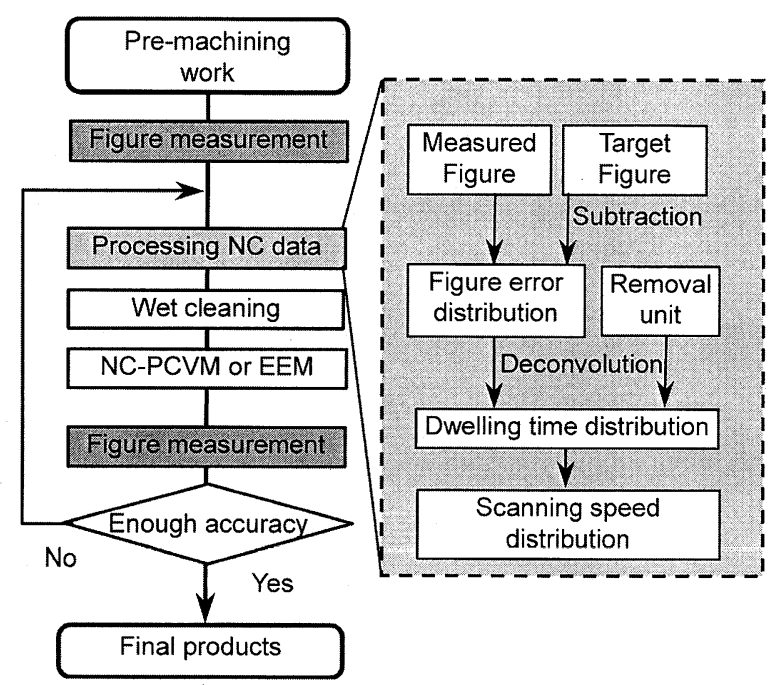

Fig. 7 Procedures of numerically controlled PCVM and EEM.

\section{4 高精度形状計測法}

このように，本加工法において数值制御加工は前加工 面形状に基づいて行われるため，加工精度は前加工面の 形状計測の精度に依存する. 従って, 高精度の加工を実 現するためには，高精度の形状計測法が不可欠である. 硬X線用ミラーへの応用を考えた場合，理想的な反射率や 集光特性を得るためには, 表面粗さから形状までの全空 間波長領域において，1 nm p-vレベルの精度が求められ る. 特に, 空間波長 $0.3 \mathrm{~mm}$ 数 $\mathrm{mm}$ の領域の凹凸は反射光 の強度ムラを発生させるため，完全に除去する必要があ る. 従って数值制御加工に使用する形状デー夕には, 0.1 $\mathrm{mm} レ$ ベルの高分解能領域と長空間波長領域の両方の領域 においてナノメートルレベルの精度が求められる。光干 渉計, 接触式形状計測 33 , LTP(Long Trace Profiler) ${ }^{34,35)}$ 等 の既存の計測器では，このような要求を満たす計測デー 夕を得ることはできない。そこで，数 $\mathrm{mm}$ 以下の短い空間 波長領域において高精計測が可能なマイケルソン型顕微 干渉計 (ZYGO NewView 200HR) と，数mm〜数百mmの中 長周期の空間波長領域において高精度計測が可能なフィ ゾー型干渉計 (ZYGO GPI XP-HR)の二つの干渉計を用い ることで，X線ミラー作製に十分な精度を有する形状計測 システム (Microstitching Interferometry; MSI)を開発し た ${ }^{36)}$ 。通常，顕微干渉計を用いて1視野に納まらない広域 形状を計測する場合，重なり部を設けながら視野をずら して全域を計測し，隣り合う計測データの重なり部の傾 斜が一致するように両者の傾きを補正して全データを繋 ぎ合わせることで，広域形状デー夕を得る。しかし，こ の方法では，繋ぎ合わせる際の角度誤差が積算され，全 体の形状としては十分な精度が得られない。開発したシ ステムでは，繋ぎ合わせる際の角度補正に，フィゾー型 干渉計による計測結果を用いることで，X線ミラーに求め られる全空間波長領域において $1 \mathrm{~nm}$ 以下の測定精度を実現 した。さらに，曲率の大きいミラーにもMSIを適用するた め, 角度参照用基準平面と高精度傾斜ステージを用い, 試料を既知角度傾斜させながらミラー全域の干渉計測を
行う, RADSI (Relative Angle Determinable Stitching Interferometry)も開発済みである ${ }^{37)}$.

\section{3. 硬X線集光用ミラーの製作}

硬X線2次元集光用ミラーの製作を試みた ${ }^{38-41)}$ 。光学系 は, SPring-8の1 km長尺ビームライン（BL29XUL)におい て，2枚の全反射楕円面ミラーをKirkpatrick-Baez (K-B) 型 に配置して集光するように設計した．Fig. 8にその概要を 示す。ミラーの大きさは長さ $100 \mathrm{~mm}$ ，幅 $50 \mathrm{~mm}$ ，厚さ 10 $\mathrm{mm}$ であり，材質は面方位 $(100)$ のシリコン単結晶であ る. 水平集光ミラーの焦点距離と楕円面最大深さはそれ ぞれ $150 \mathrm{~mm}$, 約 $16 \mu \mathrm{m}$ であり，垂直集光ミラーに関して は，それぞれ $253 \mathrm{~mm}$ ，約 $10 \mu \mathrm{m}$ である。なお，本ミラーは 全反射条件で使用するため，シリコン単体では極めて浅 くなってしまう入射角をできるだけ深くとる目的で表面 に白金を蒸着している．Fig.9に製作した2枚のミラーの形

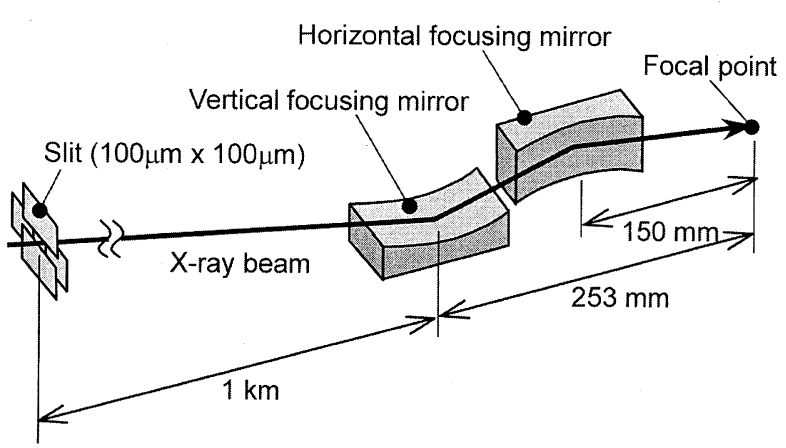

Fig. 8 Schematic of optical system for X-ray focusing using Kirkpatrick-Baez arrangement.
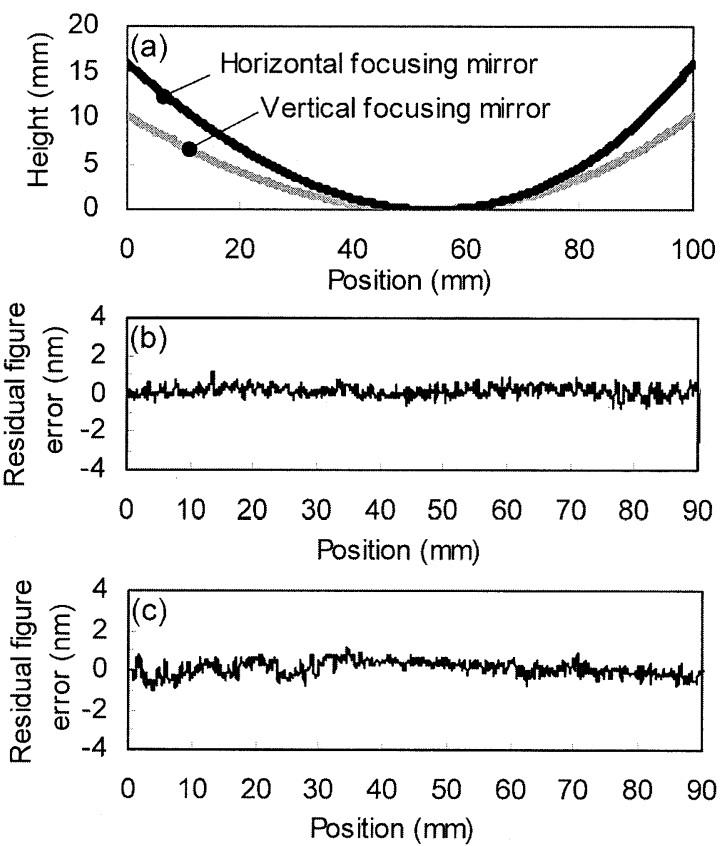

Fig. 9 (a) Figure profiles of horizontal and vertical focusing mirrors, (b) residual figure error of horizontal mirror, and (c) that of vertical mirror. 
状および形状誤差を示すが，2枚のミラーとも，形状精度 は2 nm p-v以下であることが分かる。本ミラーを用いて硬 X線 $(15 \mathrm{keV})$ を集光した結果をFig. 10に示す. 水平方向に 関しては36 nm, 垂直方向に関しては48 nmの半值幅が得 られており，極めて微細なX線プローブの形成に成功し た。なお，Fig. 10中のシミュレーション值とは，ミラー形 状として設計形状を用い, 波動光学理論に基づく計算機 シミュレーション39)を行った結果であり，回折限界に相 当するものである。測定值はシミュレーション值とよく 一致していることから，回折限界集光を達成していると 言え, 加工法, 計測法ともに十分な精度が得られた結果 と言える。製作したK-B光学系による高分解能走査型蛍光 X線顕微鏡を用いて細胞内の元素分布観察を行う共同研究 が進行中であり ${ }^{42)}$, 生命科学への貢献が大いに期待され ている。

\section{4.おわりに}

ミラーの高精度加工技術ということで, 我々のグルー プが開発してきたEEMおよびプラズマCVMについてその 概要を紹介し, 最近の成果として硬X線集光用の非球面ミ ラーの製作について紹介した。 大雑把な説明のため分か りにくい点も多々あると思われるが，詳細については参 考文献を参照いただきたい。我々は現在さらなる極限を 目指すべく，さらに微小な集光サイズを得ることが可能 な開口数 (Numerical Aperture ; NA)の大きなミラーの製作 を計画している。そのためには，より曲率の大きな非球 面形状をより高精度に製作する必要があり, 新たな形状 計測技術や形状修正技術を鋭意開発中である。なお，今 回紹介した研究は, 筆者らと理化学研究所播磨研究所の 石川哲也氏, 玉作賢治氏, 西野吉則氏, 高輝度光科学研 究センターのAlexei Souvorov氏, 矢橋牧名氏, 熊本大学 の久保田 章亀氏, ならびに大阪大学の有馬 健太氏, 稲垣 耕司氏, 斎藤彰氏等, 多くの方々との共同研究によって 行われたものである。
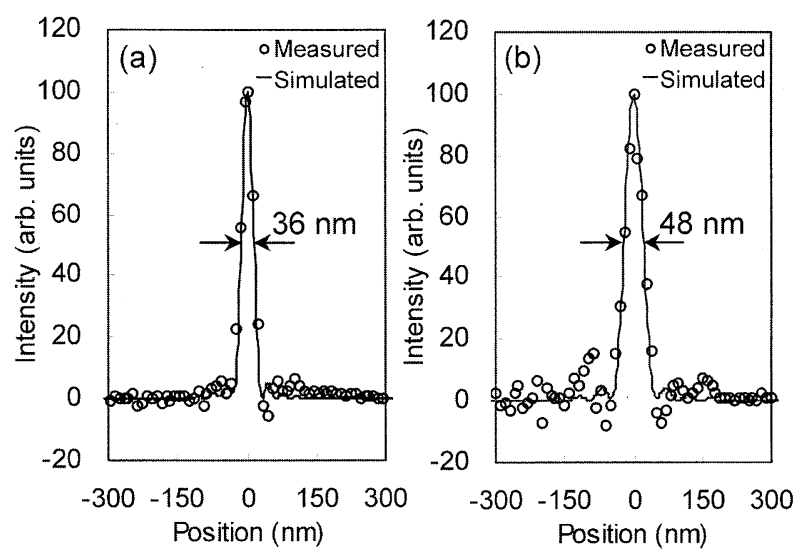

Fig. 10 (a) Intensity distribution profile of focused X-ray beam in horizontal direction and (b) that in vertical direction.

\section{参考文献}

1) A. Takeuchi, Y. Suzuki, H. Takano, and Y. Terada: Rev. Sci. Instrum. 76 (2005) 093708

2) Y. Suzuki, A. Takeuchi, H. Takano, and H. Takenaka: Jpn. J. Appl. Phys. 44 (2005) 1994.

3) G. Derst, H. Handschuh, M. Schmit, and K. Werner: Proc. SPIE 3152 (1997) 51.

4) 根岸 真人, 安藤 学, 瀧本 雅文, 出口 明信, 中村 宣夫 : 精 密工学会誌 62 (1996) 408.

5) 山下一博，笹子 勝，野村 登，新宮 克喜，持田省郎，上田 修治：超精密生産技術大系第2巻 実用技術（フジ・テクノシ ステム, 東京, 1994) 1005.

6）鈴木浩文，原成一，松永博之：精密工学会誌 59 (1993) 1713.

7) 鈴木 浩文, 小寺 直, 島野 裕樹: 精密工学会誌 60 (1994) 827 .

8）鈴木 浩文，小寺 直，中筋 智明，太田努，庄司 克雄：精密 工学会誌 63 (1997) 1280.

9) M. Weiser, J. Fröschke, H. Handschuh, M. Jülich, M. Mayer, and G. Seitz: Proceedings of 9 th International Conference on Production Engineering (1999) p. 61.

10) M. Fruit, A. Schindler, and T. Hansel: Proc. SPIE 3739 (1999) 142.

11) A. Schindler, T. Haensel, D. Flamm, A. Nickel, H. J. Thomas, and F. Big: Proceedings of 9th International Conference on Production Engineering (1999) p. 243.

12) M. Weiser: Nucl. Instrum. Meth. B80/81 (1993) 1174.

13) K. B. Becker: Proceedings of 9th International Conference on Production Engineering (1999) p. 51.

14) S. D. Jacobs, D. Golini, Y. Hsu, B. E. Puchebner, and D. Strafford: Proc. SPIE 2576 (1995) 372.

15) W. Kordonski, D. Golini, P. Dumas, and S. Hogan: Proc. SPIE 3326 (1998) 527.

16) D. Golini: Proceedings of 9th International Conference on Production Engineering (1999) p. 132.

17) D. Bollinger, G. Gallatin, J. Samuels, G. Steinberg, and C. Zarowin: Proc. SPIE 1333 (1990) 44.

18) J. Hoskins: Proc. SPIE 2542 (1995) 220.

19) G. Boehm, W. Frank, A. Schindler, A. Nickel, H. J. Thomas, F. Bigl, and M. Weiser: Proceedings of 9th International Conference on Production Engineering (1999) 231.

20) 森勇藏，山内和人，遠藤勝義：精密工学会誌 55 (1989) 480.

21）森勇藏，山内和人，杉山和久，稲垣 耕司，三村秀和，今 井 利幸: 精密工学会誌 67 (2001) 607 .

22）山内 和人，三村 秀和，久保田，章亀，有馬 健太，稲垣 耕 司，遠藤 勝義，森勇藏：精密工学会誌論文集 70 (2004) 547

23) 久保田章亀, 三村秀和, 稲垣 耕司, 森 勇藏, 山内 和人： 精密工学会誌論文集 71 (2005) 762 .

24）山内和人, 杉山和久, 稲垣耕司, 山村和也, 佐野泰久, 森勇藏：精密工学会誌 66 (2000) 630.

25）山内和人, 稲垣耕司, 三村秀和, 杉山和久, 広瀬喜久治, 森勇藏：精密工学会誌 68 (2002) 456

26) Y. Mori, K. Yamamura, K. Yamauchi, K. Yoshii, T. Kataoka, K. Endo, K. Inagaki, and H. Kakiuchi: Nanotechnology 4 (1993) 225.

27) S. Kiyama, S. Nakano, Y. Domoto, H. Hirano, H. Tarui, K. Wakisaka, M. Tanaka, S. Tsuda, and S. Nakano: Solar Energy Material. Solar Cells 48 (1997) 373.

28) H. Takino, N. Shibata, H. Itoh, T. Kobayashi, H. Tanaka, M. Ebi, K. Yamamura, Y. Sano, and Y. Mori: Jpn. J. Appl. Phys. 37 (1998) L894.

29) K. Yamamura, K. Yamauchi, H. Mimura, Y. Sano, A. Saito, K. Endo, A. Souvorov, M. Yabashi, K. Tamasaku, T. Ishikawa, and Y. Mori: Rev. Sci. Instrum. 74 (2003) 4549.

30）森勇藏, 山内和人, 山村和也, 佐野泰久: 精密工学会誌 66 (2000) 1280 .

31）森勇藏, 山内 和人, 山村和也, 三村秀和, 佐野泰久, 斎 藤彰，S. Alexei，玉作賢治，矢橋牧名，石川哲也：精密工 学会誌 68 (2002) 1347.

32) 森勇藏, 山村和也, 佐野泰久: 精密工学会誌 68 (2001) 1590.

33）根岸 真人：精密工学会誌 67 (2001) 1632.

34) P. Z. Takacs, S. Qian, and J. Colbert: Proc. SPIE 749 (1987) 59.

35) H. Li, P. Z. Takacs, and T. Oversluizen: Proc. SPIE 3152 (1997) 180 .

36）山内和人, 山村和也, 三村秀和, 佐野泰久, 久保田章亀, 
関戸 康裕，上野一匡，S. Alexei，玉作 賢治，矢橋牧名， 石川哲也，森勇藏：精密工学会誌 69 (2003) 856.

37) H. Mimura, H. Yumoto, S. Matsuyama, K. Yamamura, Y. Sano, K. Ueno, K. Endo, Y. Mori, M. Yabashi, Y. Nishino, K. Tamasaku, M. Yabashi, T. Ishikawa, and K. Yamauchi: Rev. Sci. Instrum. 76 (2005) 045102.

38) Y. Mori, K. Yamauchi, K. Yamamura, H. Mimura, A. Saito, H. Kishimoto, Y. Sekito, M. Kanaoka, A. Souvorov, M. Yabashi, T. Kenji, and T. Ishikawa: Proc. SPIE Int. Soc. Opt. Eng. 4501 (2001) 30.

39) 山内和人, 山村和也, 三村秀和, 佐野泰久, 齋藤彰, 久保田章亀，金岡政彦，S. Alexei，玉作賢治，矢橋牧名， 石川哲也，森勇藏：精密工学会誌 69 (2003) 997.
40）松山. 智至, 三村 秀和, 湯本 博勝, 原 英之, 山村和也, 佐野泰久, 西野吉則, 玉作賢治, 矢橋牧名, 石川哲也, 山内 和人：精密工学会誌論文集 72 (2006) 884.

41) H. Mimura, S. Matsuyama, H. Yumoto, H. Hara, K. Yamamura, Y. Sano, M. Shibahara, K. Endo, Y. Mori, Y. Nishino, K. Tamasaku, M. Yabashi, T. Ishikawa, and K. Yamauchi: Jpn. J. Appl. Phys. 44 (2005) L539.

42) M. Shimura, A. Saito, S. Matsuyama, T. Sakuma, Y. Terui, K. Ueno, H. Yumoto, K. Yamauchi, K. Yamamura, H. Mimura, Y. Sano, M. Yabashi, K. Tamasaku, K. Nishio, Y. Nishino, K. Endo, K. Hatake, Y. Mori, Y. Ishizaka, and T. Ishikawa: Cancer Research 65 (2005) 4998.

\section{硬X線ミラー(hard X-ray mirror)}

物質のX線に対する屈折率は 1 よりも小さいため, X線 領域においては可視光領域におけるレンズのような屈折 光学系を用いることが出来ない。また硬X線領域において は，直入射における反射率が極めて小さく，直入射反射 光学系を用いることも困難である. そのため硬X線集光に は，主にフレネルゾーンプレートや全反射光学系が用い
られているが，集光強度が必要とされる場合は全反射光 学系が適しており，楕円面鏡を 2 枚組み合わせた Kirkpatrick-Baez (K-B) 型ミラーや, 回転双曲面と回転楕円 面を組み合わせたWolter型ミラー等が用いられている。

(佐野 泰久) 